\title{
Living Teologi Tradisi Tolak Bala Bepapas pada Masyarakat Desa Parit Setia Kecamatan Jawai Kabupaten Sambas Kalimantan Barat
}

\author{
Revi Madriani \\ Jurusan Aqidah dan Filsafat Islam \\ Fakultas Ushuluddin UIN Sunan Gunung Djati Bandung, Indonesia \\ revimadriani205@gmail.com
}

\begin{abstract}
This study examines Islam that lives in the Parit Setia community. In the Parit Setia community there is a tradition tolak bala Bepapas. The purpose of this research is to answer the problems that are the subject of discussion: 1) Definition of the tradition tolak bala Bepapas; 2) Understanding the community's theology of the tradition tolak bala Bepapas; and 3) The values contained in the tradition tolak bala Bepapas. This research is a field research, with a phenomenological approach, qualitative methods, and living theology as a knife of analysis. The findings in this research show that: First, historically the tradition tolak bala Bepapas is a tradition that resulted from a mixture of culture and religion. Tradition is carried out as an effort to avoid all forms of danger, which is symbolized through leaves and is led by a traditional leader (pak Labbai). Second, this tradition has long been rooted so that it is considered sacred. Even though there are differences of opinion in responding to it, this tradition still exists today as a cultural identity of society. Third, the determination of religious values contained in this tradition is based on the principles of tawhid, which substantially have values for relating to nature, maintaining friendship, asking for salvation and as a form of gratitude to Allah SWT. Observing all the findings in the field, it is not an exaggeration to conclude that this tradition is a living Islam (living Islamic theology) in the Parit Setia community.
\end{abstract}

Keywords: Islamic theology, Parit Setia Village, Tradition Tolak Bala Bepapas.

\footnotetext{
Abstrak

Penelitian ini mengkaji Islam yang hidup di masyarakat Parit Setia. Pada masyarakat Parit Setia terdapat tradisi tolak bala Bepapas. Tujuan penelitian ini untuk menjawab permasalahan yang dijadikan pokok pembahasan: 1) Pengertian tradisi tolak
} 
bala Bepapas; 2) Pemahaman teologi masyarakat terhadap tradisi tolak bala Bepapas; dan 3) Nilai-nilai Islam yang terdapat dalam tradisi tolak bala Bepapas. Penelitian ini merupakan penelitian lapangan, dengan pendekatan fenomenologi, metode kualitatif, dan living teologi sebagai pisau analisis. Temuan dalam riset ini menunjukan bahwa: Pertama, secara historis tradisi tolak bala Bepapas ini merupakan tradisi yang dihasilakan dari percampuran budaya dan agama. Tradisi dilakukan sebagai upaya untuk menghindari segala bentuk marabahaya, yang disimbolkan melalui dedaunan dan dipimpin oleh tokoh adat (pak Labbai). Kedua, tradisi ini telah mengakar lama sehingga dianggap sakral. Meskipun terdapat perbedaan pendapat dalam menyikapinya, tetapi tradisi ini tetap eksis hingga saat ini sebagai identitas budaya masyarakat. Ketiga, penentuan nilainilai Islam yang terdapat dalam tradisi ini didasarkan pada prinsip-prinsip tauhid, yang secara subtansi memiliki nilainilai untuk berelasi dengan alam, menjaga tali silaturahmi, memohon keselamatan dan sebagai bentuk rasa syukur pada Allah Swt. Mencermati keseluruhan penemuan di lapangan maka tidak berlebihan jika penulis simpulkan bahwa tradisi ini merupakan Islam yang hidup (living teologi Islam) pada masyarakat Parit Setia.

Kata kunci: Desa Parit Setia; Teologi Islam; Tradisi Tolak Bala Bepapas.

\section{Pendahuluan}

Indonesia adalah bangsa yang kaya tradisi dan adat budaya, hal tersebut terlihat dari beragamnya tradisi dan budaya di berbagai daerah. Keragaman budaya tersebut terbentuk dari hasil cipta, karsa, dan rasa. Masyarakat dan budaya layaknya dua sisi pedang yang saling terkait. Menurut Koentjoroningrat, ada tiga wujud kebudayaan pertama, sebagai ide atau gagasan, nilai, dan norma secara kolektif yang hidup di masyarakat, serta memberi jiwa bagi masyarakat. Kedua, sebagai konsep sistem sosial untuk berinteraksi antar masyarakat. Ketiga, sebagai bendabenda yang merupakan hasil karya manusia (Sujarwa, 1999).

Upacara adat dan tradisi yang mengandung nilai dan norma dalam masyarakat, merupakan salah satu wujud kebudayaan. Di mana nilai dan norma tersebut dilaksanakan dan dipatuhi oleh masyarakat. Di Indonesia terdapat banyak sekali wujud kebudayaan dalam bentuk tradisi atau semacam ritual-ritual yang bernuansa religi atau agama, dan masyarakat 
yang melaksanakan ritual tersebut merupakan masyarakat yang masih percaya dengan unsur-unsur mistik. Masyarakat Indonesia dari dulu hingga hari ini masih banyak yang percaya pada benda-benda yang dianggap memiliki kekuatan gaib, seperti batu, pohon, keris, pedang, dedaunan, dan lain-lain. Sehingga dari kepercayaan tersebut, manusia harus menjalin hubungan baik dengan alam, yaitu dengan mengadakan upacara simbolik, membacakan do'a, serta memberikan sesaji. Dengan begitu alam pun akan berlaku baik terhadap manusia, dan manusia pun akan terbebas dari roh jahat (Jamil A. ,2000). Bagi masyarakat yang percaya akan adanya kekuatan-kekuatan supranatural dan kekuatan yang lebih tinggi, mereka khawatir akan terjadi marabahaya yang akan menimpa mereka, sehingga lahirlah sebuah kepercayaan upacara tradisi.

Islam adalah agama yang lentur sehingga dapat menyesuaikan dengan ajaranya, dan kondisi suatu masyarakat di daerah tersebut. Dengan kelenturannya itu, Islam dapat diterima dengan mudah oleh masyarakat Indonesia. Dari kelenturan ini juga lah, yang kemudian menghasilkan akulturasi antara budaya lokal dengan Islam, sehingga lahirlah sebuah keragaman dalam tradisi di Indonesia (Soehadha, 2016). Agama Islam memberikan warna yang begitu nyentrik dalam tradisi atau adat di masyarakat. Bahkan keduanya sangat sulit untuk dibedakan, karena dua unsur ini saling terikat dan terkait, dan menjadi suatu kebiasaan dalam kehidupan masyarakat. Di Indonesia banyak sekali tradisi yang dianggap sakral dan memiliki nilai praktis dalam kehidupan, dengan begitu tradisi tersebut dikukuhkan sebagai bagian dari syariat Islam, misalnya tradisi yang berkaitan dengan kehidupan seperti perkawinan, kehamilan, kelahiran, dan kematian (Syarbini, 2011).

Islam di Indonesia, khususnya di Kalimantan Barat dibawa oleh Syarif Abdurrahman al-Kadri yang merupakan putra dari Habib Husein al-Kadri (Admin, 2011), menyebarkan Islam dengan cara yang halus merupakan contoh pendekatan Islam dengan memasukan nilai-nilai ajaran Islam dalam unsur-unsur budaya lokal. Hal tersebut dilakukan agar masyarakat dapat dengan mudah menerima ajaran Islam serta dapat mengaplikasikannya dalam kehidupan. Masyarakat Kalimantan Barat merupakan masyarakat Melayu, dikenal sebagai masyarakat yang religius dan patuh dalam menjalakan ajaran Islam. Hal tersebut dapat terlihat dengan banyaknya tempat ibadah (Langgar), dan pondok pesantren di setiap pemukiman warga. Selain itu masyarakat di Kalimantan Barat, masih menjunjung tinggi nila-nilai kebersamaan, kerukunan, maupun kekerabatan. Jika melihat akan hal tersebut, maka tidak heran masih banyak kebudayaan-kebudayaan lokal yang mengandung nilai-nilai Islam dan masih terus dilestarikan, salah satu contohnya adalah tradisi tolak bala Bepapas. 
Tradisi tolak bala Bepapas merupakan salah satu tradisi yang masih dilaksanakan oleh masyarakat desa Parit Setia Kecamatan Jawai Kabupaten Sambas Kalimantan Barat. Tradisi tolak bala Bepapas ini biasanya dilaksanakan setiap hari Jumat, sebagai ekspresi rasa syukur masyarakat desa Parit Setia pada Allah Swt dan sebagai bentuk penghormatan terhadap leluhurnya. Dalam keyakinan masyarakat desa Parit Setia, jika tradisi tolak bala Bepapas ini tidak dilaksanakan maka akan terjadi sesuatu hal yang tidak diinginkan. Berdasarkan keterangan masyarakat Parit Setia (Halida, Apa dampak jika tradisi ini tidak dilaksanakan?, 2021), suatu waktu tradisi tolak bala Bepapas itu pernah tidak dilaksanakan, dan ternyata benar bahwa hal-hal yang tidak diinginkan itu terjadi, sebagaimana yang ia tuturkan sebagai berikut:

“ia waktu itu kakak saya mau pergi ke Malaysia, dan di perjalanannya mengalami kecelakaan, karena tidak melakuan tolak bala dulu. Padahal sebelumnya sudah diingatkan oleh Ibu dan Ayah saya. Soalnya keluarga saya ini sangat percaya banget dengan ritual tolak bala Bepapas ini, jadi kalo tidak dilaksakan akan gelisah dan khawatir banget" (Halida, Apa dampak jika tradisi ini tidak dilaksanakan?, 2021).

Dalam prosesi tradisi tolak bala Bepapas tersebut terdapat beberapa bahan-bahan yang menjadi syarat wajib, di antaranya seperti daun injuang, daun gimbali, daun mentibar, daun ribu, air kasai langgir, tempurung kelapa dan ditutup dengan bacaan do'a selamat. Daun-daun tersebut kemudian dicelupkan kedalam air kasai langgir yang ada di dalam tempurung kelapa. Setelah itu, dipukulkan ke orang yang melakukan hajat dari kepala hingga ke kaki. Hal ini dimaksudkan seseorang sebelum melakukan sesuatu agar berpikir terlebih dahulu. Tradisi tolak bala Bepapas ini sudah menjadi bagian dari kehidupan masyarakat Parit Setia yang tidak bisa dipisahkan. Masyarakat desa Parit Setia meyakini bahwa tradisi ini memiliki banyak manfaat untuk menjalin kehidupan sosial dan budaya yang ada di sana.

Dalam menyikapi tradisi tersebut terdapat perbedaan pendapat, ada sebagian masyarakat yang kurang antusias karena takut ada unsur-unsur menyimpang yang mengarah pada kemusyrikan atau menyekutukan Allah. Namun, sebagian masyarakat lain menanggapinya biasa saja dan tidak menganggap tradisi tolak bala Bepapas ini ada unsur-unsur musyriknya. Justru, bagi mereka tradisi ini merupakan ekspresi masyarakat untuk bermunajat atau berdo'a pada Allah, di mana yang dalam pelaksanaan dilakukan bersama-sama sehingga disepakati oleh sebagian masyarakat sebagai norma-norma dalam mengatur sistem kepercayaan. 
Dari perbedaan tersebut dapat disimpulkan bahwa masing-masing masyarakat di desa Parit Setia memiliki pandangan yang berbeda. Selain itu yang lebih menarik adalah bahwa tradisi tolak bala Bepapas ini memiliki nilai-nilai yang berbeda dengan tradisi lainnya. Di tengah perkembangan zaman dan kemajuan teknologi yang begitu pesat, masyarakat Parit Setia masih melestarikan tradisi tolak bala Bepapas. Namun, hal tersebut tidak menjadikan masyarakat Parit Setia menolak perkembangan zaman dan kemajuan teknologi. Karena hal tersebut terlihat dari gaya hidup dan cara bergaul dengan menggunakan teknologi dalam kehidupan sehari-harinya.

Kendatipun, dari gaya hidup dan cara bergaulnya sudah beradaptasi dengan kemajuan zaman, namun masyarakat Parit Setia masih melestarikan kebudayaan-kebudayaan warisan nenek moyang yang di dalamnya terdapat unsur-unsur ajaran Islam, salah satunya tradisi tolak bala Bepapas. Di dalam prosesi ritual tradisi ini kaya akan ritual-ritual yang bercorak kepercayaan lama. Penggunaan dedaunan dan air kasai langgir merupakan beberapa ciri yang corak ritual atau sesembahan lama pada masa pra-Islam. Dari semua syarat bahan-bahan dan proses yang ada dalam ritual tradisi tolak bala Bepapas tersebut, tentu ada nilai-nilai kehidupan yang menjadi landasan dan tujuan bagi masyarakat.

Berangkat dari uraian tersebut, penulis tertarik untuk mendalami lebih jauh pemahaman masyarakat Parit Setia terkait dengan living teologi. Living Teologi adalah teologi yang hidup di masyarakat, atau kehidupan teologi di masyarakat. Living Teologi merupakan kajian untuk memahami tradisi-tradisi keagamaan yang hidup di masyarakat Muslim, yang tidak hanya sekedar memahami apa yang tampak atau yang hadir dalam tradisi tersebut, tetapi mencari apa yang menjadi dasar dan landasan tradisi tersebut. Oleh karena itu lah, penulis akan membahas konsep living teologi sebagai sebuah perspektif untuk menganalisis tradisi tolak bala Bepapas pada masyarakat desa Parit Setia. Konsep living teologi merupakan upaya gagasan lanjutan dari konsep teologi pembebasan, teologi pembangunan, teologi lingkungan, teologi kerukunan, teologi sosial, ataupun teologi lainnya yang berkaitan erat dengan kehidupan masyarakat (Aziz, 2020).

Berikut beberapa kajian relevan sebelumnya yang patut untuk diulas. Ritual Tolak Bala pada Masyarakat Melayu Kajian pada Masyarakat Petalangan Kecamatan Pangkalan Kuras Kabupaten Pelalawan yang ditulis oleh Hasbullah (2017). Artikel ini menguraikan ritual tolak bala yang dilakukan masyarakat Patalangan, yang mana masyarakat Patalangan ini merupakan masyarakat muslim. Dijelaskan bahwa ritual tolak bala yang dilakukan masyarakat Patalangan ini mengandung sinkretisme agama yang di dalamnya terdapat perpaduan unsur agama Budha, Hindu, dan Islam. Selain itu, juga mengandung unsur animisme dan dinamisme. Artikel ini menjelaskan ritual tolak bala pada masyarakat Patalangan ini dinilai 
memberikan manfaat seperti untuk menjauhkan diri dari mara bahaya (Hasbullah, 2017).

Gustrianto (2017) menelaah Nilai-nilai Tradisional Tolak Bala Di Desa Betung Kec. Pangkalan Kuras Kab. Palalawan. Artikel ini membahas ritual tolak bala yang dilakukan di desa Betung, ritual tolak bala ini dipahami masyarakat memiliki nilai-nilai tradisional. Ritual tolak bala menurut masyarakat Betung adalah ritual untuk menjauhkan diri dari mala petaka, gangguan jin, dan makhluk halus. Tradisi ini dilakukan masyarakat Betung secara turun temurun dari leluhur mereka. Karena pada dasarnya masyarakat desa Betung melakukan ritual tolak bala ini atas dasar memenuhi janji kepada leluhurnya karena telah diberikan sesuatu. Tradisi ritual tolak bala ini dilakukan pada awal bulan dan jika tidak dilakukan dipercayai masyarakat Betung akan mendapatkan bala petaka (Gustiranto, 2017).

Triwahyuni (2020) menulis Tradisi Sedekah Tolak Bala pada Masyarakat Desa Langkan Kecamatan Banyuasin III Kabupaten Banyuasin. Dalam tulisannya ia mengulas tradisi tolak bala yang dilakukan masyarakat Banyuasin yakni dengan melakukan sedekah. Masyarakat Banyuasin meyakini tradisi tolak bala dengan melakukan sedekah ini dapat memberikan rasa tolong-menolong, selalu mengingat Allah SWT, dan untuk mempererat tali silaturahmi antar sesama. Prosesi pelaksaannya dengan melakukan do'a bersama dan memberikan makanan pada keluarga dan masyarakat yang diundang. Masyarakat melakukan tolak bala dengan melakukan sedekah sebagai cara untuk berikhtiar dalam menghadapi malapetaka yang mungkin akan terjadi (Triwahyuni, 2020).

Beberapa studi di atas, mengulas tradisi tolak bala dengan berbagai perspektifnya. Terlepas ada persamaan dalam metodologi dan lainnya, namun tulisan ini akan mengulas tradisi tolak bala di desa Parit Setia dalam perspeftif konsep living teologi. Yang mana kajian living teologi sampai saat ini masih terus diwacanakan dan dicarikan format epistemologi keilmuannya, terutama dalam hal integrasi-interkoneksi dan studi keislaman dengan ilmu-ilmu lainnya.

Tujuan penelitian ini untuk menjawab beberapa permasalahan yang dijadikan pokok pembahasan, yakni meliputi: 1) Pengertian tradisi tolak bala Bepapas; 2)Pemahaman teologi masyarakat Parit Setia terhadap tradisi tolak bala Bepapas; dan 3) Nilai-nilai Islam yang terdapat dalam tradisi tolak bala Bepapas.

\section{Literature Review}

Bambang Qomaruzzaman (2020) dalam bukunya yang berjudul "Belajar Teologi di Tengah Pandemi" dijelaskan bahwa Teologi secara umum sebenarnya berkisar pada tiga kategori yaitu: Teologi sebagai wacana, Teologi yang dilakonkan (Lived Teologi), dan Teologi yang berkembang 
sejauh dipahami masyarakat (Living Teologi). Teologi sebagai wacana adalah sejumlah konsep teologi sebagaimana dalam khazanah pemikiran Islam. Di Universitas Islam misalnya, mata kuliah yang membicarakan Teologi sebagai wacana adalah Ilmu Kalam yang berisi tinjauan historis dan substansi teologi Islam seperti Khawarij, Murji'ah, Mu'tazilah, Syiah, Asyariyah, Maturidiyah, Jabariyah, Qadariyah, dan sejenisnya (Qomaruzzaman, 2020).

Lived Teologi adalah teologi yang dilakonkan. Pelaku Lived Teologi adalah siapapun yang secara sadar menerapkan prinsip-prinsip tauhid dalam menjalankan hidupnya. Secara umum, para ustadz, kyai, da'i, dan pemikir Muslim merupakan pelaku utama dari lived teologi. Tidak terkecuali juga mahasiswa adalah pelaku teologi jika ia secara sadar menggunakan prinsip-prinsip tauhid untuk memahami realitas, menemukan masalah dalam realitas, seraya mengajukan solusi (konseptual dan/atau praksis) atas masalah tersebut.

Sementara Living Teologi membicarakan teologi sebagaimana dipraktekkan oleh masyarakat. Pelakunya adalah masyarakat, entah tukang sapu, tukang baso, ibu Rumah Tangga, Polisi, bukan tokoh pemilik otoritas keagamaan (ulama, ustadz, pemikir, sarjana agama, mahasiswa agama). Pemahamannya bisa jadi "tidak sesuai" dengan doktrin resmi teologi, bisa jadi secara sengaja melakukan "tafsir tersendiri" atau karena keterbatasan pengetahuan sehingga secara tidak sengaja memberikan "tafsir tersendiri" atas doktrin. Sengaja atau tidak sengaja "tafsir tersendiri" ini diterima sebagai kreativitas (atau bahkan inovasi) orang beriman dalam mengkontekstualisasikan doktrin teologi Islam di tengah kehidupannya (Qomaruzzaman, 2020).

Living Teologi yang dimaksud dalam tulisan ini berdasar pada Islamic living teologi, yang memiliki sandaran konsep lebih luas yakni living Islam. Living Islam, sejauh ini diartikan sebagai Islam yang hidup di masyarakat atau kehidupan Islam di masyarakat. Kajian living teologi muncul sebagai wacana untuk menghadirkan Islam yang hidup di masyarakat, dan menggulirkan pandangan bahwa Islam tidak hanya sekedar doktrin. Sebagai sebuah konsep yang sedang tumbuh, gagasan ini hadir dengan lahirnya buku-buku dan sejumlah artikel dari penulis, seperti Magnus Marsden, Fida Sanjakdar, Akbar S. Ahmad, dan Herry Nurdi. Dari karyakarya tersebut dapat dipahami bahwa living Islam merupakan gambaran atas keseharian Islam (Islam today) yeng terkait ruang dan waktu pada suatu masyarakat (Zuhri, 2018).

Dari gagasan living Islam tersebut, munculah kajian living Qur'an yang diartikan sebagai al-Qur'an yang hidup di masyarakat, atau al-Qur'an yang diaktualisasikan dalam kehidupan sehari-hari (Heddy Shri, 2012). Dalam buku Living the Qur'an: In Our Time, Jamal Khwaja (2012) mengulas wawasan fiosofis dan teologis sebagai upaya mempelajari semantik al- 
Qur'an dan visinya. Dalam buku tersebut ia menguraikan kenapa agama tradisional gagal dalam merespon tantangan modernitas. Selain itu, ia juga mengeksplorasi prinsip-prinsip dasar Islam yang menekankan etika dan moral untuk saling menghormati antar sesama, sehingga dapat berkontibusi dalam menumbuhkan identitas Islam di tengah kehidupan masyarakat yang multibudaya (Khwaja, 2012).

Selain itu, ada juga konsep living sunnah (Darmalaksana, Alawiah, Thoyib, Sadi'ah, \& Ismail, 2019), yang digagas oleh Fazlur Rahman (19191988), konsep ini disebut sebagai hukum tingkah laku, baik itu mental maupun fisik. Sebagaimana yang ia katakan berikut:

"What we want now to do is recast hadith in to living sunnah term by historical interpretation so that we may be able to drive norms from it for ourselves through an adequate etical theory and its legal reembodint" (Rahman, 1965).

Dari gagasannya tersebut Rahman menghendaki adanya upaya penuangan kembali hadis-hadis Nabi dalam bentuk living sunnah. Dengan tujuan untuk menghidupkan dan mengaplikasikan nilai-nilai hadis dalam konsep living sunnah, sebagai langkah untuk mengadaptasi hal-hal baru yang sesuai dengan kebutuhan dan tantangan masyarakat muslim kontemporer.

Uraian di atas menggambarkan bahwa suatu konsep disandingkan dengan term living, mengandung makna sebagai bentuk pengungkapan atas fenomena aktual yang sedang terjadi, dialami, dihayati, atau diperjuangkan oleh suatu komunitas. Jika living Islam menggambarkan bagaimana Islam yang hidup hari ini (Islam today), diinterpretasikan dan diaktualisasikan oleh suatu masyarakat pada waktu tertentu, maka living teologi merujuk pada aspek-aspek pemikiran, keyakinan, penghayatan, perasaan, dan kehidupan keseharian seseorang atau suatu kelompok masyarakat. Misalnya living teologi Santri, mengandung makna berteologi bersama santri, di mana santri tidak hanya menjadi objek dari teologi, melainkan ia juga menjadi subjek dari teologi itu sendiri. Hal tersebut dipicu oleh kesadaran teologis dan harapan yang dimiliki oleh suatu komunitas santri di Pesantren tersebut.

Sebagai suatu konsep yang terhitung baru, living teologi masih terus harus menyesuaikan diri dan merangkul keilmuan lainnya yang telah mapan. Karena mesti diakui bahwa, living teologi masih belum menjadi suatu konsep atau terminologi keilmuan yang dirumuskan secarah utuh, berbeda halnya dengan kajian antropologi Islam yang relatif lebih mapan dan telah mempunyai basis masyarakat akademis tersendiri. Oleh karena itu, basis teori yang dirujuk oleh living teologi adalah living Islam atau dengan kata lain living teologi merupakan sub bagian dari Islamic Studies. 
Secara umum living teologi merupakan bagian dari konsep living Islam, yakni merupakan suatu perspektif untuk memahami tradisi-tradisi keagamaan yang hidup di masyarakat Muslim. Dengan demikian konsep living teologi berkaitan erat dengan dimensi kebudayaan, dalam arti sebagai keseluruhan gagasan, pemikiran, keyakinan, perbuatan, maupun kreasi. Konsep ini berpusat pada pikiran dan perasaan manusia yang kemudian dijadikan acuan dalam melakukan kegiatan, dan dalam menafsirkan realitas kehidupannya (Zuhri, 2018).

Istilah living teologi (Islam) berasal dari kata, living dan teologi (Islam). Dalam kamus bahasa Inggris kata living adalah bentuk adjective dari kata kerja live yang berarti hidup. Living juga sering diberi makna yang hidup atau kehidupan. Maka, living teologi (Islam) berarti Teologi yang hidup di masyarakat atau kehidupan teologi Islam di masyarakat. Living Teologi merupakan kajian untuk memahami tradisi-tradisi keagamaan yang hidup di masyarakat Muslim, yang tidak hanya sekedar memahami apa yang tampak atau yang hadir dalam tradisi tersebut, tetapi mencari apa yang menjadi dasar dan landasan tradisi tersebut (Zuhri, 2018).

Adapun unsur-unsur dalam living teologi yaitu: 1) tradisi yang hidup. Tradisi yang hidup dimaknai sebagai adat kebiasaan yang turun-temurun dilaksanakan oleh suatu masyarakat atau yang dilakukan secara berulangulang dari waktu ke waktu oleh masyarakat; 2) adanya perangkat keras dan perangkat lunak. Perangkat keras ialah seperti bangunan, monument atau benda-benda yang menjadi simbol keagamaan, manuskrip-manuskrip keagamaan, serta pelaku atau subjeknya itu sendiri sebagai penganut agama Islam atau orang Muslim baik dalam arti individual maupun dalam konteks kolektif kemasyarakatan. Perangkat lunak yaitu seperti, ajaran, sumber (referensi), praktik keagamaan, nilai, ide, dan keyakinan (Zuhri, 2018).

Keduanya eksis dalam praktik-praktik kemasyarakatan dan melekat dalam tradisi yang dibangun dengan landasan norma-norma tertentu yang ada dalam dimensi keislaman; 3) Kekuatan historis. Kekuatan historis penting untuk mengidentifikasi bahwa living teologi tidak semata fakta yang tampak, tetapi juga fondasi historis yang sudah mengakar lama di masyarakat. Pengertian tradisi yang mengakar lama di masyarakat lebih diarahkan pada fakta-fakta historis yang menunjukan adanya acuan atau referensi yang ditunjukan kepada para pendahulu masyarakat (intelektual Muslim) yang memang scara turun-temurun dari satu generasi ke generasi berikutnya telah melakukan kreasi keagamaan sebagai bentuk dari imajinasi kreatif yang dilakukan oleh intelektual Muslim dalam menerjemahkan gagasan-gagasan keagamaan ke dalam bentuk yang lebih aplikatif dan konkrit, sehingga masyarakat melakukannya sebagai wujud pembuktian dan pengakuan eksistensi mereka (Zuhri, 2018). 
Berdasarkan hal tersebut, ruang lingkup dan batasan living teologi adalah sebagai berikut. Pertama, dari sisi subyek yang dikaji, dapat mencakup individu,suatu komunitas, maupun masyarakat. Sepanjang mereka masih hidup di alam ini, dan berinteraksi dengan sesama, keberadaannya dapat menjadi subyek studi yang tidak hanya akan bermanfaat bagi dirinya, namun juga untuk orang lain. Kedua, dari sisi obyek, ruang lingkupnya mencakup aspek keyakinan, pemahaman, tradisi, dan implementasinyadalam kehidupan. Berbeda dengan teologi Islam klasik yang fokusnya pada hal-hal yang bersifat ketuhanan, living teologi lebih mengarah pada bentuk konkret pengalaman berteologi dalam dinamika sosial dan kemanusiaan

Atas dasar itulah, dalam batas-batas tertentu konsep living teologi sebagai sebuah perspektif ini, akan digunakan untuk menganalisis tradisi tolak bala Bepapas pada msyarakat Parit Setia. Agar dapat melihatnya secara utuh, mendalam, objektif, dan komprehensif.

\section{Metode Penelitian}

Penelitian ini termasuk jenis penelitian lapangan (Darmalaksana, Metode Penelitian Kualitatif Studi Pustaka dan Studi Lapangan, 2020), dengan menggunakan pendekatan Fenomenologi. Sebagai metode fenomenologi digunakan Husserl untuk memilah dan memilih segala fenomena yang tampak, apakah fenomena itu asli atau palsu, dan melihat realitas sejernih mungkin atau sampai pada hakikat yang sebenarnya (Masykur, 2013). Selain itu, untuk pengumpulan data menggunakan metode kualitatif, seperti observasi, wawancara, dan dokumentasi. Observasi merupakan studi yang dilakukan secara sistematis tentang fenomena sosial dan gejala-gejala alam melalui pengamatan dan pencatatan. Wawancara dilakukan untuk memperdalam pengumpulan data setelah dilakukannya observasi. Dokumentasi merupakan catatan peristiwa yang sudah berlalu. Dokumen bisa berbentuk tulisan, gambar, atau karya-karya monumental dari seseorang. Teknik dokumentasi merupakan pelengkap dari teknik observasi dan wawancara yang telah dilakukan (Sugiyono, 2014).

Sumber data yang digunakan yaitu data primer dan sekunder. Data primer diperoleh langsung dari sumber pertama, yaitu masyarakat dan tokoh adat desa Parit Setia. Sementara data sekunder adalah data pendukung atau data tambahan yang diperoleh dari sumber-sumber yang berkaitan dengan pembahasan penelitian yang akan dilakukan, seperti buku, jurnal, skripsi, artikel, dan karya ilmiah lainnya (Azwar, 1999).

Kemudian, penentuan Informan dalam penelitian ini menggunakan teknik purposive sampling (sampling bertujuan). Teknik ini merupakan teknik penentuan sampel melalui pertimbangan-pertimbangan tertentu. Pertimbangan tersebut dilakukan seperti menentukan informan atau 
seseorang yang dianggap paling mengetahui tentang apa yang akan dibutuhkan dalam penelitian, atau seseorang tersebut merupakan penguasa atau seseorang yang memiliki posisi tertentu, sehingga akan memudahkan peneliti untuk menjelajahi, atau memperoleh data dari objek atau situasi yang akan diteliti (Sugiyono, 2014).

Analisis data merupakan hal yang kritis dalam proses penelitian. Analisis digunakan untuk memahami hubungan dan konsep dalam data sehingga analisis dapat dikembangkan dan dievaluasi, dengan pengujian secara sistematis untuk menentukan hubungan antar bagian, dan hubungan secara keseluruhan. Data yang diperoleh peneliti sebelum dianalisis, terlebih dahulu dikumpulkan sesuai dengan jenis data masingmasing. Selanjutnya, dianalisis dengan teori yang dijadikan pisau analisis dalam riset ini yaitu living teologi. Analisis dilakukan sesuai hasil observasi, wawancara dan dokumentasi.

Adapun waktu dan tempat dalam penelitian ini, yaitu di Desa Parit Setia Kecamatan Jawai Kabupaten Sambas Kalimantan Barat dan dilakukan dari akhir bulan Desember 2020 sampai Maret 2021. Penelitian ini dilakukan pada 6 (enam) orang informan yang meliputi: Ijas (pak labbai/tokoh adat), Rumila (tokoh agama), Halim (masyarakat), Halida (masyarakat), Fadinsi (masyarakat), dan Said (masyakarat). Keenam informan tersebut dipilih berdasarkan teknik purposive sampling, karena dianggap mampu merepresentasikan perihal tradisi tolak bala Bepapas.

\section{Hasil dan Pembahasan}

Desa Parit Setia merupakan salah satu desa yang ada di kecamatan Jawai Kabupaten Sambas Provinsi Kalimantan Barat. Desa Parit Setia terletak di wilayah pesisir pantai dan perkebunan masyarakat. Letak desa Parit Setia tepat di sebelah Utara kecamatan Jawai. Mayoritas penduduknya berprofesi sebagai nelayan dan petani dan sebagian ada juga yang berprofesi sebagai TKI di Malaisya. Masyarakat desa Parit Setia mayoritas beragama Islam dan bersuku Melayu Sambas.Budaya yang dimiliki masyarakat desa Parit Setia yang bersuku Melayu Sambas banyak dipengaruhi oleh tradisi leluhur nenek moyang. Di desa Parit Setia kondisi dan suasananya masih perkampungan karena letaknya yang berada di pulau kecil, menjadikan masyarakat desa Parit Setia hingga saat ini masih cukup menjaga tradisi adat budayanya.

Perbedaan pemahaman akan teologi mewujud dalam berbagai sisi kehidupan masyarakat. Hal tersebut, merupakan kesatuan unsur-unsur yang komprehensif, yang kemudian menunjukkan seseorang disebut beragama (being religious), dan tidak hanya sebatas mengakui memiliki agama (having religion). Tradisi tolak bala Bepapas merupakan gambaran ekspresi masyarakat Parit Setia yang tidak hanya berhenti pada aspek ritual saja, melainkan mencerminkan sikap sosial baik terhadap sesama maupun 
terhadap alam semesta. Unsur-unsur motivasi kehidupan, meyakini sesuatu hal yang ghaib, seluk-beluk usaha dan harapan cukup mewarnai pengalaman batiniyah masyarakat Parit Stia. Bertitik tolak pada hasil riset di lapangan, gambaran keberagamaan dalam tradisi tolak bala Bepapas pada masyarakat Parit Setia, akan diulas sebagai berikut:

\section{Tradisi Tolak Bala Bepapas}

\section{a) Fondasi Historis}

Secara historis, di daerah kabupaten Sambas terdapat kerajaan Sambas yang merupakan kerajaan terbesar dan tertua di Kalimantan Barat. Penemuan benda-benda arkeologis dan beberapa patung Hindu menjadi bukti telah berdirinya kerajaan. Kerajaan Sambas popular sekitar abad ke14 dan menjadi Negara vassal kerajaan Majapahit. Pada waktu itu, Sambas merupakan wilayah yang dikuasi oleh Melayu yang tidak identik dengan Islam, namun lebih cenderung dengan Hindu.

“Namun, Melayu di sini bukanlah Melayu yang identik dengan Islam, melainkan lebih dekat dengan agama Hindu, karena Suku Melayu yang masuk ke Sambas pada abad ke-11 menurut Johan Weintre (2004; 20) adalah Melayu yang membawa unsur-unsur Hindu dari Kerajaan Sriwijaya dan Majapahit" (Risa, 2014).

Hal tersebut menjadi bukti bahwa adat budaya yang ada di suku Melayu banyak dipengaruhi oleh kebiasaan orang-orang Hindu. Begitupun dengan tradisi tolak bala Bepapas, yang merupakan warisan budaya yang sudah ada sejak lama. Diperkirakan tradisi tolak bala Bepapas ini adalah peninggalan budaya orang-orang Hindu yang kemudian ikuti oleh orangorang Islam terutamanya suku Melayu Sambas. Hal ini sesuai dengan yang dikatakan oleh Said berikut:

“Yang saya pernah dengar cerita sejarah tradisi tolak bala Bepapas ini adalah peninggalan sejarah budaya Hindu yang sudah ada sejak zaman Majapahit. Namun, begitu Islam masuk ke sini yang dibawa oleh Abdurrahman al-Kadri yang merupakan putra dari Habib Husein al-Kadri, tradisi ini akhirnya diimprovisasi menjadi tradisi orang Islam di sini, dengan memasukan ajaran-ajaran Islam di dalamnya" (Said, Sejarah Tradisi Tolak bala Bepapas, 2021).

Budaya masyarakat Sambas mengalami banyak perkembangan dari zaman ke zaman, hingga saat ini semakin menanamkan nilai-nilai agama Islam. Hal ini karena masyarakat Sambas telah banyak mempelajari ilmu pengetahuan dan keagamaan. Begitupun dengan tradisi tolak bala Bepapas 
ini merupakan hasil akultrasi budaya dan agama yang ada di Sambas. Sebagaimana yang diungkapkan Halim sebagai berikut:

“Untuk secara pastinya saya juga kurang tau sejarahnya, yang pasti sejak dahulu sudah ada tradisi Bepapas. Setau saya jaman nenek dan kakek saya sudah ada tradisi Bepapas itu dan bahkan sebelum mereka ada juga sudah ada. Kalau menurut saya, tradisi tolak bala Bepapas ini merupakan hasil akultrasi budaya dan agama yang dijadikan kebiasaan oleh masyarakat" (Halim, 2021).

Tradisi tolak bala Bepapas ini sangat mudah ditemukan di setiap daerah di kabupaten Sambas salah satunya di desa Parit Setia. Tradisi Bepapas ini dapat diartikan kedalam bahasa Indonesia yakni berasal dari kata be yang berarti melakukan, sedangkan papas memiliki makna memukul. Sehingga dapat dipahami bahwa tradisi Bepapas ini memiliki arti melakukan sesuatu dengan cara dipukul atau memukul (Berti, Tradisi Bepapas Sebagai Media Dakwah Di Desa Sumber Harapan Kecamatan Sambas, 2021).

Tradisi tolak bala Bepapas ini biasanya dilakukan dalam rangka pindah rumah, syukuran mendapatkan sesuatu ataupun jika ingin berpergian jauh, yang pada intinya dilakukan untuk membuang atau menjauhkan bahaya. Hal tersebut sesuai dengan yang disampaikan Ijas berikut:

“Tradisi tolak bala Bepapas ini biasanya dilakukan untuk syukuran, tolak bala, berpergian jauh, pindah rumah baru, pengantin.Masyarakat desa Parit Setia mempercayai dengan adanya tradisi tolak bala Bepapas ini dapat menjauhkan diri mereka ataupun keluarga mereka dari bahaya yang akan datang" (Ijas, 2021).

Dari uraian di atas, dapat disimpulkan bahwa tradisi tolak bala Bepapas ini merupakan tradisi yang dihasilkan dari pencampuran budaya Hindu dan agama Islam. Proses percampuran antara budaya dan agama ini dilakukan masyarakat dengan menjalankan tradisi yang sudah turun temurun dilakukan dengan mengaitkannya dengan ajaran-ajaran agama Islam. Sehingga masyarakat percaya bahwa meskipun tradisi tolak bala Bepapas ini berasal dari kebiasaan orang Hindu, akan tetapi tradisi tersebut sudah mengalami akultrasi dengan ajaran-ajaran agama Islam.

\section{b) Prosesi Ritual Tradisi Tolak Bala Bepapas}

Sebagaimana telah diuraikan sebelumnya, bahwa tradisi ini biasanya dilakukan dalam acara syukuran, pindah rumah baru, berpergian, maupun setelah mendapat musibah. Pada initinya tradisi tolak bala Bepapas ini, 
dilakukan sebagai usaha untuk menolak bala dan bentuk rasa syukur kepada Allah Swt. Adapun alat yang digunakan dalam tradisi tolak bala Bepapas yakni daun injuang, daun gimbali, daun mentibar yang diikat menggunakan daun ribu, air kasai langgir dan tempurung kelapa untuk wadahnya. Setelah semuanya terikat, kemudian dicelupkan kedalam air beras dan dipukulkan kepada orang yang melakukan hajat mulai dari kepala hingga kaki sembari dibacakan do'a selamat oleh pak Labbai (tokoh adat). Setelah melakukan pemukulan dedaunan tersebut kepada orang yang melakukan hajat, pak Labbai pun mengajak semua yang menghadiri acara tolak bala Bepapas tersebut melakukan do'a bersama dengan membacakan sholawat dan do'a selamat. Dalam tradisi tolak bala Bepapas ini, tidak dianjurkan menggunakan selain dedaunan yang sudah disebutkan itu karena masyarakat desa Parit Setia meyakini dedaunan tersebut memiliki nilai dan makna. Hal ini sesuai dengan yang disampaikan Said berikut:

"Dalam melakukan tradisi Bepapas ini tidak pernah menggunakan selain daun Injuang, daun Gimbali, daun Mentibar dan daun Ribu. Adapun daun-daun itu diikat dengan daun Ribu, karena sudah dari sejak dulu dianjurkan seperti itu" (Said, 2021).

Prosesi tradisi tolak bala Bepapas ini biasanya dilakukan pada hari Jumat pagi sekitar pukul 06.00 WIB. Masyarakat desa Parit Setia meyakini bahwa tradisi ini dilakukan pada hari Jum'at pagi akan membawa keberkahan. Hal tersebut didasarkan karena masyarakat percaya bahwa hari Jumat dalam Islam memiliki makna yang baik. Maka dari itu, masyarakat desa Parit Setia dalam melakukan prosesi tradisi tolak bala Bepapas ini dilakukan pada hari Jum'at pagi. Sebagaimana yang diungkapkan oleh Fadinsi berikut:

“Tolak bala Bepapas ini dilakukan di hari Jum’at pagi karena untuk mencari keberkahan hari Jum'at, dalam Islam kan hari Jum'at itu Ibunya hari. Selain itu, kami melakukannya dengan banyak-banyak sedekah memberi makanan kepada orang" (Fadinsi, Pelaksanaan Tradisi Tolak Bala Bepapas Pada Hari Jumat, 2021).

Dalam prosesi tradisi tolak bala Bepapas ini, orang yang ingin melakukan hajat mengundang atau mengajak orang-orang terdekat untuk datang pada acara Bepapas di rumahnya. Selain mengajak, ia juga menyiapkan berbagai menu wajib untuk acara tersebut seperti ketupat dan rateh. Penggunaan menu ketupat dan rateh menjadi menu wajib karena sudah dilakukan secara turun temurun hingga menjadi kebiasaan. Setelah pembacaan do'a yang dipimpin oleh pak Labbai kemudian semua tamu 
undangan disuguhi makanan dan minuman sebelum pulang. Seperti yang diungkapkan Said berikut:

“Untuk makanan dalam tradisi tolak bala Bepapas ini pasti menunya Ketupat dan Rateh, karena makanan ini sudah menjadi pelengkap apabila setelah melakukan Bepapas, maka dari itu kami menyajikan makanan tersebut" (Said, 2021).

Dapat kita pahami bahwa tradisi tolak bala Bepapas ini, dapat dilakukan dalam berbagai acara seperti, pindah rumah baru, syukuran, ataupun sengaja berhajat untuk menolak bala. Dalam pelaksanaanya tradisi tolak bala Bepapas ini dilakukan pada hari Jumat Pagi dengan alasan agar mendapat keberkahan. Begitupun dengan menu makanan yang wajib dihidangkan dalam tradisi tolak bala Bepapas ini adalah ketupat dan rateh. Semua bahan-bahan maupun menu makanan yang wajib dalam tradisi tolak bala Bepapas ini sudah ditentukan sejak lama dan dilakukan secara turun-menurun.

\section{Pemahaman Masyarakat pada Tradisi Tolak Bala Bepapas}

Masyarakat desa Parit Setia adalah masyarakat yang mayoritas beragama Islam. Dalam melakukan keberlangsungan hidup, hingga saat ini masyarakat desa Parit Setia masih menjaga dan melakukan berbagai tradisi yang diwariskan leluhur. Meskipun beragama Islam, sebagian besar masyarakat desa Parit Setia masih mempercayai hal-hal yang berkaitan dengan kekuatan gaib. Akan tetapi, sebagian besar juga sudah tidak mempercayainya karena memiliki pandangan lain. Masyarakat desa Parit Setia meyakini tradisi tolak bala Bepapas sebagai kebiasaan dalam menolak bala. Masyarakat memahami tradisi tolak bala Bepapas ini memiliki keterkaitan dengan agama Islam. Hal tersebut diungkapkan Ijas berikut:

"Masyarakat desa Parit Setia yang masih melakukan tradisi tolak bala Bepapas dan tidak meninggalkannya, selain karena untuk menjaga tradisi warisan para leluhur, juga sebagai bentuk bermunajat pada Allah supaya dihindarkan dari segala bahaya. Ya meskipun, sebagian masyarakat ada yang meninggalkannya karena menganggap tradisi ini mengandung unsur-unsur syirik, karena dalam prosesinya menggunakan dedaunan" (Ijas, 2021).

Tradisi tolak bala Bepapas ini banyak mendapat kritikan dari sebagian masyarakat desa Parit Setia yang sudah tidak mempercayai tradisi ini. Bahkan ada yang beranggapan tradisi ini merupakan perilaku menyimpang dan mengarah kepada kemusyirikan. Sebagaimana yang dituturkan Fadinsi berikut: 
"Saya dan keluarga saya dan kerabat saya sudah meninggalkan tradisi Bepapas ini, karena menurut kami tradisi ini udah gak relevan lagi dengan zaman hari ini. Meskipun, dalam prosesi pelaksanaannya menggunakan do'a-do'a ajaran Islam, tapi di dalamnya masih menggunakan dedaunan yang sebenarnya tidak memiliki nilai dan makna sebagaimana yang mereka yakini, hal itu seperti menyerupai cara ibadah orang-orang agama lain (selain Islam) yang menyembah dewa-dewa. Kalo misalnya tujuan mereka melakukan ritual tersebut untuk memohon keselamatan, kan dalam Islam sudah diatur tata caranya yaitu dengan rajin ibadah dan berdo'a pada Allah. Jadi, udah cukuplah ikuti saja aturan Islam insyaallah kita semuanya selamat" (Fadinsi, 2021).

Akan tetapi, bagi masyarakat yang meyakini tradisi ini menganggap tidak menyimpang. Dengan alasan, karena penggunaan bahan-bahannya mengandung nilai dan makna. Kemudian do'a yang dipanjatkan pun terdiri dari syahadat, sholawat, al- Fatihah dan do'a-do'a keselamatan lainnya. Seperti yang diungkpakan Fadinsi berikut:

"Menurut saya, tradisi Bepapas itu bukan syirik karena merupakan adat tradisi yang hanya dibacakan sholawat dan doa selamat karena do'ado'a itu juga merupakan senjata umat Islam. Soalnya waktu itu saya juga pernah menghadiri acara syukuran lahiran anak tetangga saya yang juga melakukan tradisi Bepapas di rumahnya. Dalam acaranya saya tidak menemukan pemakaian mantra atau do'a-do'a yang dianggap aneh, yang saya lihat acaranya itu menggunakan do'a-do'a selamat yang tujuannya meminta perlindungan kepada Allah SWT. Bahkan waktu itu saya diberi buku panduan acaranya untuk dibaca bersama-sama, yang saya baca menggunakan do'a selamat seperti Rabbanaa Aatinaa Fiddunyaa Hasanah Wa Fil Akhirati Hasanah Wa Qina A'za bannar, dan sholawat Allahumma Sholli ‘Aala Syaidinaa Muhammad“ (Rumila, 2021).

Masyarakat desa Parit Setia yang meyakini tradisi tolak bala Bepapas ini akan menjauhkan diri dari bahaya. Begitupun jika tidak melakukannya, masyarakat beranggapan akan mendapatkan bahaya. Maka dari itu, masyarakat pun menjadi terikat untuk selalu melakukan tradisi ini dalam menolak bala ataupun bentuk bersyukur.

“Tradisi tolak bala Bepapas sampai saat ini masih dilakukan keluarga saya karena masih percaya dengan adanya menolak bala, karena keluarga saya merasa terikat dengan tradisi Bepapas ini, jika tidak melakukannya diyakini akan ada bahaya. Biasanya tradisi Bepapas ini untuk syukuran dan meminta dijauhkan dari marabahaya. Keluarga saya setiap ingin 
melakukan syukuran pasti terlebih dahulu melakukan Bepapas" (Halida, 2021).

Dari uraian di atas, dapat dipahami bahwa tradisi tolak bala Bepapas ini dilakukan sebagai bentuk ikhtiar masyarakat dalam menolak bala. Akan tetapi, dalam pelaksanaanya tradisi tolak bala Bepapas ini mendapat pro dan kontra dari masyarakat. Hal ini karena sebagian masyarakat desa Parit Setia masih ada yang melaksanakannya dan sebagian sudah tidak mengerjakannya karena dipengaruhi oleh beberapa hal seperti dianggap menyimpang. Masyarakat desa Parit Setia yang hingga kini masih melaksanakan tradisi tolak bala Bepapas ini menganggap bahwa dalam tradisi tersebut ada nilai-nilai Islam.

\section{Nilai-nilai Islam dalam Tradisi Tolak Bala Bepapas}

Tradisi tolak bala Bepapas ini memiliki makna yang tersirat jika dihubungkan dengan Islam yakni memberikan pesan aqidah, syariah, dan akhlak. Masyarakat desa Parit Setia meyakini bahwa dengan melakukan tradisi tolak bala Bepapas ini dapat mendekatkan hubungan manusia dengan Allah Swt. Melalui berbagai bahan-bahan yang digunakan dalam tradisi tolak bala Bepapas ini masing-masing memiliki makna. Begitupun dengan do'a yang dipanjatkan untuk meminta perlindungan kepada Allah Swt. Sebagaimana yang dikatakan Rumila berikut:

“Masyarakat yang masih menjalankan tradisi tolak bala Bepapasini percaya dengan peran Allah Swt dalam melindungi manusia. Masyarakat menggantungkan harapan agar dilindungi oleh Allah Swt. Maka dari itu, masyarakat desa Parit Setia meyakini melalui tradisi tolak bala Bepapas ini dapat menolong masyarakat mendekatkan diri kepada Sang Pencipta" (Rumila, 2021).

Tradisi tolak bala Bepapas ini juga biasa dilakukan dengan bersedekah atau berbagi makanan kepada orang-orang sekitar. Masyarakat meyakini bahwa sebagian dari rezeki yang mereka miliki adalah hak orang lain yang harus diberikan. Dengan melakukan tradisi tolak bala Bepapasini merupakan bentuk rasa syukur masyarakat atas rejeki ataupun keselamatan yang diberikan Sang Maha Pencipta. Selain itu juga bentuk ikhtiar untuk memohon perlindungan dari segala marabahaya yang kapan saja bisa datang. Hal tersebut sesuai dengan yang diungkapkan Rumila:

“Dalam tradisi tolak bala Bepapas ini banyak pelajaran yang dapat diambil dan memiliki hubungan dengan ajaran agama Islam.Manfaat dari tradisi tolak bala Bepapas ini menumbuhkan rasa syukur dan senantiasa berbagi kepada sesama. Manusia tidak hanya bisa mengharapkan kekuatan 
do'a saja, akan tetapi juga harus berusaha (ikhtiar). Segala permohonan dipanjatkan kepada Allah Swt agar diberi keselamatan di dunia. Masyarakat mempercayai dengan tradisi tolak bala Bepapas ini tidak hanya ingin memohon perlindungan saja. Akan tetapi juga memiliki nilai ibadah kebaikan lainnya, salah satunya antara sesama manusia" (Rumila, 2021).

Dalam pelaksanaan tradisi tolak bala Bepapas ini masyarakat mengungkapkan penggunaan dedauan dan air kasai langgir ini memiliki makna di antaranya; Daun Injuang memiliki makna bahwa dalam hidup ini penuh perjuangan dan jangan menyia-nyiakan waktu selama di dunia karena segala perbuatan akan dipertanggungjawabkan di akhirat nanti. Daun Mentibar ini memiliki makna yakni sebagai manusia yang tidak luput dari dosa. Manusia adalah ciptaan Allah Swt yang ketika diberi ujian hidup semestinya harus sabar dan ikhlas menghadapinya. Sebagai umat Islam yang taat kepada Allah Swt seharusnya manusia dapat mengambil pelajaran atas setiap yang Allah Swt berikan karena di balik ujian tersebut pasti ada hikmahnya. Air Kasai Langgir ini juga biasa disebut dengan air tepung beras yang dicampur dengan langgir dan dibacakan do'a selamat oleh tokoh adat. Air kasai langgir dengan do'a selamat ini memiliki makna bahwa manusia memanjatkan do'a untuk menggantungkan harapan kepada Sang Pencipta Allah Swt. Harapannya ialah memohon perlindungan dan keselamatan dari berbagai marabahaya. Daun Gimbali ini memiliki arti bahwa manusia itu harus memiliki sifat mawas diri atau menjaga diri dari berbagai bahaya.

Meskipun pada hakikatnya manusia hanya bisa berusaha untuk menjauhkan diri dari bala atau marabahaya. Akan tetapi, melalui tradisi tolak bala Bepapas ini merupakan bentuk ikhtiar kepada Allah Swt. Daun Ribu ini merupakan daun yang dijadikan pengikat untuk daun-daun lainnya. Daun Ribu ini memiliki makna sebagai pengikat hubungan antara sesama umat Islam seperti dalam hubungan tali silaturahmi yang harus dijaga. Selain itu daun Ribu ini juga memiliki makna sebagai permohonan meminta rezeki kepada Allah Swt yang melimpah ruah dalam kehidupan manusia (Berti, 2021).

Dalam tradisi tolak bala Bepapas ini dianggap memiliki nilai-nilai baik bagi masyarakat yang melakukannya. Tradisi tolak bala Bepapas ini tidak hanya sekedar dilakukan untuk menolak bala saja melainkan juga memiliki nilai teologis. Maka dari itu, hingga sampai saat ini masih banyak masyarakat yang melakukan tradisi tolak bala Bepapas ini. Masyarakat masih mempercayai kesakralan tradisi tolak bala Bepapas ini dalam menolak bala.

"Menurut saya, nilai-nilai Islam dari tradisi tolak bala Bepapas ini ialah kebersaman yang dilakukan masyarakat desa Parit Setia dan dapat 
menghubungkan tali silaturahmi sesama umat Islam. Selain itu, dengan melakukan tradisi tolak bala Bepapas ini dianggap dapat menjaga tradisi budaya masyarakat Melayu Sambas yang ada di desa Parit Setia. Kemudian juga meningkatkan rasa syukur dan bersedekah kepada sesama masyarakat ataupun sanak saudara. Masyarakat masih mempercayai tradisi tolak bala Bepapas ini karena dianggap sebagai momen untuk mendekatkan diri kepada Sang Maha Pencipta. Karena pada hakikatnya makna tradisi tolak bala Bepapas ini adalah meminta kepada Allah SWT untuk dijauhkan dari marabahaya" (Ijas, 2021).

Tradisi tolak bala Bepapas ini sebagai tradisi yang berkaitan dengan ajaran Islam, dan hal ini dibuktikan dengan setiap memberikan tawar atau mantra selalu dengan do'a-do'a yang dianjurkan dalam Islam. Acara tolak bala Bepapas dilakukan dalam acara seperti syukuran, pindah rumah baru, dan hajatan untuk menolak bala. Tradisi tolak bala Bepapas ini adalah untuk meminta keselamatan kepada Allah SWT karena sebagai ciptaan-Nya sudah sepatutnya kita memohon dengan Allah SWT. Selain meminta keselamatan tradisi tolak bala Bepapas juga bertujuan untuk bersedekah kepada sesama.

Selain itu, sebagai bentuk rasa syukur atas limpahan rezeki dan keselamatan yang diberikan Sang Maha Pencipta. Masyarakat desa Parit Setia memahami bahwa hanya kepada Allah Swt satu-satunya tempat bergantung meminta perlindungan. Dengan memanjatkan doa selamat untuk meminta pertolongan Allah Swt agar diberi keselamatan dalam kehidupan.

\section{Analisis Living Teologi Tradisi Tolak Bala Bepapas}

Sebagaimana yang telah diulas sebelumnya bahwa Living Teologi adalah teologi yang dipahami dan dipraktekan oleh masyarakat. Living Teologi merupakan kajian untuk memahami tradisi-tadisi keagamaan yang hidup di masyarakat Muslim, yang tidak hanya sekedar memahami apa yang tampak atau yang hadir dalam tradisi tersebut, tetapi mencari apa yang menjadi dasar dan landasan tradisi tersebut. Jika melihat temuan akan fakta di desa Parit Setia, maka Islam yang hidup di sana adalah tradisi tolak bala Bepapas yang akan diulas sebagai berikut:

\section{a) Kekuatan Historis}

Kekuatan historis penting untuk mengidentifikasi bahwa living teologi tidak semata fakta yang tampak, tetapi juga fondasi historis yang sudah mengakar lama di masyarakat. Pengertian tradisi yang mengakar lama di masyarakat lebih diarahkan pada fakta-fakta historis yang menunjukan adanya acuan atau referensi yang ditunjukan kepada para pendahulu masyarakat (intelektual Muslim) yang memang secara turun-temurun dari 
satu generasi ke generasi berikutnya telah melakukan kreasi keagamaan sebagai bentuk dari imajinasi kreatif yang dilakukan oleh intelektual Muslim dalam menerjemahkan gagasan-gagasan keagamaan ke dalam bentuk yang lebih aplikatif dan konkrit, sehingga masyarakat melakukannya sebagai wujud pembuktian dan pengakuan eksistensi mereka.

Pada konteks tradisi tolak bala Bepapas, tradisi ini pada mulanya merupakan tradisi yang dilakukan oleh agama masyarakat sebelumnya yakni agama Hindu. Tradisi ini dilakukan untuk mengusir roh jahat agar terhindar dari berbagai bahaya. Tradisi masyarakat tersebut terus dilakukan hingga berdirinya kerajaan Sambas di kabupaten Sambas. Kerajaan Sambas merupakan kerajaan yang di bawah kekuasaan kerajaan Majapahit. Maka dari itu, banyak pengaruh budaya dari kerajaan Majapahit yang masuk dalam kerajaan Sambas. Di kerajaan Sambas ini dikuasai oleh orang Melayu yang lebih cenderung ke adat budaya agama Hindu bukan Islam. Hal ini karena pada waktu itu, Islam belum secara menyeluruh dipahami masyarakat sebagai agama, melainkan hanya sebagai agama formalitas saja. Dari hal tersebut, banyak budaya dan pemahaman yang berkembang di masyarakat salah satunya ialah tradisi menolak bala.

Tradisi tersebut berakulturasi dengan ajaran Islam dibawa oleh Abdurrahman al-Kadri yang merupakan putra dari Habib Husein al-Kadri. Abdurrahman al-Kadri mengimprovisasi tradisitolak bala ini sebagai jalan dakwah dalam Islam. Seperti yang diutarakan oleh tokoh Adat (pak Labbai) berikut:

"Iya dulu itukan (tahunnya lupa) masyarakat Sambas ini mayoritas beragama Hindu, dan masih percaya dengan ritual-ritual yang berbau magis. Jadi, penyebaran Islam di sini itu pendekatannya melalui apa kesukaan atau kebiasaan masyarakat, dan tradisi tolak bala ini merupakan salah satu kebiasaan masyarakat di sini. Dari situ, akhirnya Islam yang dibawa oleh Abdurrahman al-Kadri ini bisa diterima masyarakat tanpa menghilangkan kebiasaan atau identitas masyarakat di sini. Ya, sama aja dengan penyebaran yang dilakukan para Wali di Jawa si, sampai hari ini masih kita saksikan betapa leturnya agama Islam yang bisa masuk di berbagai tempat tanpa menghilangkan identitas budaya masyarakat" (Ijas, 2021).

Dari fakta historis di atas, menjadi bukti bahwa tradisi tolak bala Bepapas ini merupakan media dakwah bagi Abdurrahman al-Kadri, agar Islam dapat diterima oleh masyarakat di sana. Islam yang masuk di Sambas khususnya di desa Parit Setia identik dengan tradisi-tradisi lokalnya. Sebagaimana tradisi tolak bala Bepapas ini yang awalnya merupakan 
kebiasaan umat Hindu yang bertujuan untuk mengusir roh jahat, kini telah bertransformasi menjadi kebiasaan umat muslim di sana dengan tujuan untuk mendapatkan perlindungan dari Allah, melalui tradisi yang sama namun berbeda dalam do'a-do'a yang dibacakannya.

\section{b) Perangkat Keras dan Perangkat Lunak dalam Tradisi Bepapas}

Dalam living teologi (Islam) perangkat keras dan perangkat lunak, menjadi hal penting apakah tradisi tersebut termasuk dalam kategori Islam yang hidup di masyarakat atau tidak. Perangkat keras ialah seperti bangunan, monument atau benda-benda yang menjadi simbol keagamaan, manuskrip-manuskrip keagamaan, serta pelaku atau subjeknya itu sendiri sebagai penganut agama Islam atau orang muslim baik dalam arti individual maupun dalam konteks kolektif kemasyarakatan. Perangkat lunak yaitu, seperti ajaran, sumber (referensi), praktik keagamaan, nilai, ide, dan keyakinan.

Dalam prosesi tradisi tolak bala Bepapas penggunaan daun Injuang, Mentibar, Gimbali, daun Ribu, Air Kasai Langgir dan Tempurung Kelapa sebagai wadah air kasai langgir merupakan perangkat keras yang ada dalam tradisi tolak bala Bepapas. Sementara, perangkat lunak dalam tradisi ini yaitu, pemahaman dan keyakinan masyarakat terhadap nilai dan makna yang disimbolkan melalui dedaunan dan do'a yang dibacakan dalam prosesi tradisi tolak bala Bepapas. Hakikatnya penggunaan dedaunan dalam tradisi ini melambangkan kehidupan manusia yang harus bisa berdampingan dengan alam semesta dan harus saling menjaga. Hal tersebut diungkapkan tokoh Adat (pak Labbai) berikut:

"Dedaunan yang digunakan dalam tradisi tolak bala Bepapas ini menurut kami melambangkan kehidupan, iya dedaunan yang hijau itu melambangkan kehidupan kan?. Karena dalam hidup kita itu tidak bisa hidup sendiri, kita harus saling berdampingan, entah itu dengan sesama manusia maupun dengan alam. Melalui dedaunan yang hijau dari tumbuhan inilah kita bisa menghirup udara yang segar. Dan pembacaan do'a-do'a selamat ini juga yang dimaksudkan untuk memohon perlindungan dari Allah agar terhidar dari segala bahaya" (Ijas, 2021).

Hal penting lainnya, pemilihan hari dan penetuan waktu dalam prosesi tradisi tolak bala Bepapas ini, tidak sekedar memilih hari tetapi didasarkan pada prinsip tauhid. Seperti dilaksanakan pada hari jum'at, dalam Islam hari jum'at itu merupakan Ibunya hari, sehingga masyarakat Parit setia meyakini jika tradisi ini dilakukan di hari itu akan mendatangkan keberkahan. Kemudian penentuan jam 06:00 pagi, hal ini berlandaskan pada pemahaman masyarakat yang meyakini bahwa pagi itu 
adalah aba-aba dalam menjalani hari, jadi sebelum melaluinya diawali dengan do'a. Berikut pernyataan masyarakat terkait pemilihan hari dan penentuan jamnya:

“Dalam Islam itu sebenarnya semua hari itu baik, tapi hari jum'at itu merupakan Rajanya hari atau dalam Islam disebut dengan sayyidul ayyam, yang disebutkan juga dalam hadis Nabi riwayat Ahmad dan Ibnu Majah. Dan tradisi tolak bala Bepapas yang sekarang ini tentu berbeda dengan yang dilakukan umat Hindu sebelumnya. Terus kenapa jam 6 pagi, ya karena pagi itu kan aba-aba jadi sebelum kita melakukan aktivitas atau kegiatan baiknya diawali dulu dengan berdo'a pada Allah" (Rumila, 2021).

Mencermati uraian di atas, dapat dipahami bahwa, dalam prosesi ritual tolak bala Bepapas baik dalam perangkat keras maupun perangkat lunak penentuan dan pemilihan yang digunakannya didasarkan pada prinsip tauhid. Hal ini bisa kita lihat, sebagaimana yang telah dipaparkan di atas. Selain itu, meskipun pada mulanya tradisi ini merupakan tradisi umat Hindu, tetapi secara subtansi telah berbeda, karena dalam pelaksanaanya masyarakat telah memasukan nilai-nilai Islam di dalamnya. Oleh karenanya, masyarakat menganggap bahwa tradisi ini merupakan tradisi umat muslim di desa Parit Setia yang akan terus dijaga kelestariannya.

\section{c) Tradisi Tolak Bala Bepapas sebagai Tradisi yang Hidup}

Tradisi yang hidup dimaknai sebagai adat kebiasaan yang turuntemurun dilaksanakan oleh suatu masyarakat atau yang dilakukan secara berulang-ulang dari waktu ke waktu oleh masyarakat. Tradisi yang berkembang di masyarakat akan senantiasa dilakukan karena dianggap memiliki nilai-nilai kehidupan.

Begitupun dengan tradisi tolak bala Bepapas yang ada di masyarakat Melayu Sambas tepatnya di desa Parit Setia. Masyarakat desa Parit Setia telah melakukan tradisi tolak bala Bepapas ini sejak lama dan dipahami memiliki nilai-nilai Islam bagi kehidupan bersama. Seperti yang telah dipaparkan sebelumnya bahwa pemaknaan terhadap tradisi tolak bala Bepapas ini tidak diperoleh melalui cocokologi, melainkan didasarkan pada prinsip-prinsip tauhid. Hal tersebut sesuai dengan yang disampaikan oleh tokoh Adat (pak Labbai) berikut:

“Penggunaan dedaunan ini bagi kami melambangkan kehidupan, kita bisa menghirup udara bersih itu ya karena adanya alam yang hijau dan terjaga. Ikatan tali yang menyatukan semua dedaunan ini melambangkan kesalingan atau silaturahmi yang harus kita jaga, silaturahmi yang dimaksud di sini tidak sebatas sesama manusia tetapi pun dengan alam dan 
semua makhluk Allah. Apalagi kan Islam itu rahmat bagi seluruh alam, jadi kita sebagai orang Islam harus mewujudkan konsep tersebut agar tidak hanya sekedar menjadi selogan saja" (Ijas, 2021).

Dari keterangan tokoh Adat (pak Labbai) tersebut, menjadi penegasan bahwa tradisi Bepapas ini memang sudah menjadi suatu tradisi yang diyakini masyarakat Parit Setia. Tidak hanya sekedar ritual-ritual yang nampak saja, akan tetapi memiliki nilai-nilai teologis yang subtansinya sangat Islami. Di mana tokoh adat (pak Labbai) menyinggung bahwa Islam itu merupakan rahmat bagi alam semesta, akan mewujud jika kita sebagai umat muslim mengaktualisasikannya dalam kehidupan sehari-sehari dan tidak menjadikannya sebatas selogan semata.

Hal menarik lainnya yang penulis temukan ialah, keterangan tokoh agama yang mengatakan bahwa penentuan dan pemilihan hari dan waktu dalam pelaksanaan tradisi ini berlandaskan pada ajaran-ajaran Islam. Sehingga tradisi ini benar-benar menjadi eksperesi masyarakat Parit Setia baik dalam berelasi dengan alam, sesama manusia, semua makhluk Allah, dan sebagai bentuk bermunajat untuk mendapatkan perlidungan Allah dari segala marabahaya. Berikut keterangan tokoh agama Parit Setia:

"Dalam Islam tradisi itu dikenal dalam konsep 'urf, 'urf itu merupakan suatu kebiasaan masyarakat yang sudah dikenal. Nah, banyak macamnya ada 'urf shahih yaitu kebiasaan yang tidak merusak aqidah sehingga diperbolehkan. Sedangkan, 'urf fasid adalah kebiasaan yang merusak aqidah sehingga tidak diperbolehkan. Untuk melihat apakah suatu kebiasaan tersebut dibolehkan atau tidak itu kembali pada niatnya. Tradisi Bepapas ini menurut saya termasuk tradisi yang dibolehkan karena kami yang melakukan tradisi ini niatnya untuk hal-hal baik dan memohon perlindungan Allah" (Rumila, 2021).

Dari seluruh uraian di atas, dapat penulis simpulkan bahwa tradisi tolak bala Bepapas ini telah menjadi tradisi yang hidup dalam masyarakat desa Parit Setia. Melalui tradisi tolak bala Bepapas ini masyarakat menemukan kenyamanannya dalam mengekepresikan diri untuk berelasi dengan alam, sesama manusia, maupun dengan Tuhannya. Baik dilihat dari sisi kekuatan historis, perangkat keras, maupun tradisi yang hidup, tradisi tolak bala Bepapas ini telah memenuhi ketiganya. Oleh karena itu, tidak berlebihan jika penulis menyimpulkan bahwa tradisi ini merupakan Islam yang hidup (living teologi Islam) di masyarakat Parit Setia.

\section{Kesimpulan}

Berdasarkan temuan akan fakta yang ada di masyarakat Parit Setia telah menghasilkan beberapa kesimpulan. Pertama, secara historis tradisi tolak bala Bepapas ini merupakan tradisi yang dihasilkan dari percampuran 
budaya (kebiasaan orang Hindu) dan agama (ajaran Islam). Tradisi dilakukan sebagai upaya untuk menghindari segala bentuk marabahaya, yang disimbolkan melalui dedaunan dan dipimpin oleh tokoh Adat (pak Labbai). Kedua, tradisi ini telah mengakar di masyarakat sehingga dianggap memiliki nilai-nilai yang sakral dalam kehidupan bersama. Meskipun terdapat perbedaan pendapat dalam menyikapinya, tetapi tradisi ini tetap eksis hingga saat ini sebagai identias budaya masyarakat muslim Parit Setia. Ketiga, penentuan nilai-nilai Islam yang terdapat dalam tradisi ini didasarkan pada prinsip-prinsip tauhid, sehingga secara subtansi terlihat jelas perbedaan mendasar dengan yang dilakukan oleh umat Hindu sebelumnya. Tolak bala Bepapas telah menjadi tradisi masyarakat muslim di Desa Parit Setia dengan nilai-nilai Islami di dalamnya, yakni untuk berelasi dengan alam, menjaga tali silaturahmi antara sesama, meminta keselamatan dan sebagai bentuk rasa syukur kepada Allah Swt. Mencermati keseluruhan penemuan di lapangan maka tidak berlebihan jika penulis simpulkan bahwa tradisi ini merupakan Islam yang hidup (living teologi Islam) pada masyarakat Parit Setia.

Akhirnya betapapun cukup singkat kajian ini, setidaknya ini dapat memberikan gambaran yang memadai terkait living teologi Islam tradisi tolak bala Bepapas pada masyarakat desa Parit Setia. Kendatipun begitu, temuan-temuan dalam penelitian ini memiliki kemungkinan untuk salah. Dengan perkataan lain, argumen-argumen penulis tentang tradisi tolak bala Bepapas masyarakat desa Parit Setia, perlu untuk dikaji ulang dalam kajian-kajian selanjutnya. Oleh karena itu, semestinya kajian ini dapat menjadi undangan untuk memulai kajian berikutnya.

\section{Daftar Pustaka}

Admin. (2011, Februari 09). Perkembangan Islam di Kalimantan Barat.

Dipetik April 09, 2021, dari Kalbariana:

https:/ / kalbariana.web.id/perkembangan-islam-di-kalimantanbarat/

Alfan, M. (2013). Filsafat Kebudayaan. Bandung: Pustaka Setia.

Azaransky, C. M. (2017). Lived Theology New Perspectives On Method, Style And Pedagogy. New York: Oxford University Press .

Aziz, A. A. (2020). Living Teologi: Religiusitas dan Hubungan Sosial

Pedagang Kaki Lima. Jurnal Theologia, 31(1), 87-114.

Azwar, S. (1999). Metode Penelitian. Jakarta: Pustaka Pelajar.

Berti, E. (2021). Tradisi Bepapas sebagai Media Dakwah di Desa Sumber Harapan Kecamatan Sambas. Jurnal SAMBAS:(Studi Agama, Masyarakat, Budaya, Adat, Sejarah) Journal of Religious, Community, Culture, Costume, History Studies, 3(2), 95-119.

Darmalaksana, W. (2020). Metode Penelitian Kualitatif Studi Pustaka dan Studi Lapangan. Pre-Print Digital Library UIN Sunan Gunung Djati 
Bandung.

Darmalaksana, W., Alawiah, N., Thoyib, E. H., Sadi'ah, S., \& Ismail, E. (2019). Analisis Perkembangan Penelitian Living Al-Qur'an dan Hadis. Jurnal Perspektif.

Fadinsi. (2021, April 9). Pelaksanaan Tradisi Tolak Bala Bepapas Pada Hari Jumat. (R. Madriani, Interviewer)

Gustiranto, G., \& Tantoro, S. (2017). Nilai-nilai Tradisional Tolak Bala di Desa Betung Kecamatan Pangkalan Kuras Kabupaten Pelalawan (Doctoral dissertation, Riau University).

Halida. (2021, April 9). Pemahaman Masyarakat Terhadap Tradisi Tolak Bala Bepapas. (R. Madriani, Interviewer)

Halim. (2021, April 9). Tradisi Tolak Bala Bepapas Akultrasi Budaya. (R. Madriani, Interviewer)

Hanafi, A. (1995). Pengantar Teologi Islam. Jakarta: Al Husna Zikra.

Hardiansyah, H. (2013). Teori Pengetahuan Edmund Husserl. Substantia: Jurnal Ilmu-Ilmu Ushuluddin, 15(2), 226-236.

Hasbullah, H., Toyo, T., \& Pawi, A. A. A. (2017). Ritual Tolak Bala Pada Masyarakat Melayu (Kajian Pada Masyarakat Petalangan Kecamatan Pangkalan Kuras Kabupaten Pelalawan). Jurnal ushuluddin, 25(1), 83100.

Ahimsa-Putra, H. S. (2012). The Living Al-Qur'an: Beberapa Perspektif Antropologi. Walisongo: Jurnal Penelitian Sosial Keagamaan, 20(1), 235260.

Hendriansyah, H. (2021). Metode Penelitian Kualitatif. Jakarta: Salemba Humanika.

Ijas. (2021, Maret 10). Pandangan Masyarakat Terhadap Tradisi Tolak Bala Bepapas. (Revi, Interviewer)

Jamil, A. (2000). Islam dan Kebudayaan Jawa. Yogyakarta: Gama Media.

Jayadi. (n.d.). Makna Tradisi Bepapas Dalam Masyarakat Sambas. Retrieved from : http/ / / www.nukhatulistiwa.com

Khwaja, J. (2012). Living the Qur'an: in Our Time. New Delhi: Sage Publication.

Lacy, C. (1983). Book Review: Living Theology in Asia.

Masykur, A. R. (2013). Sejarah Filsafat Barat. Yogyakarta: IRCiSoD.

Mustafa, M. D. (2006). Reorientasi Teologi Islam dalam Konteks Pluralisme Beragama. HUNAFA: Jurnal Studia Islamika, 3(2), 129-140.

Mustansyir, R. (2016). Kearifan Lokal Masyarakat Melayu Sambas Tinjauan Filosofis. Yogyakarta: Fakultas Filsafat.

Permata, C. (n.d.). Bentuk Dan Makna Penamaan Tempat Di Kecamatan Jawai Kab. Sambas . Retrieved from https ://jurnal.untan.ac.id

Qomaruzzaman, B. (2020). Belajar Teologi di Tengah Corona. Bandung.

Rahman, F. (1965). Islamic Methodologi in History. Islamabad: Islamic Research Institute. 
Risa. (2014). Islam Di Kerajaan Sambas Antara Abad XV - XVII : Studi Awal Tentang Islamisasi Di Sambas. Jurnal Khatulistiwa, 105.

Rumila. (2021, April 9). Kritik Terhadap Pelaksanaan Tradisi Tolak Bala Bepapas. (R. Madriani, Interviewer)

Said. (2021, April 9). Menu Makanan Pada Tradisi Tolak Bala Bepapas. (R. Madriani, Interviewer)

Soehadha, M. (2016). Tauhid budaya: Strategi sinergitas Islam dan budaya lokal dalam perspektif antropologi Islam. Tarjih: Jurnal Tarjih dan Pengembangan Pemikiran Islam, 13(1), 15-32.

Sugiyono. (2014). Metode Penlitian Kuantitatif dan Kualitatif. Bandung: Alfabeta.

Sujarwa. (1999). Manusia dan Fenomena Budaya Menuju Perspektif Moralitas Agama. Yogyakarta: Pustaka Pelajar.

Sulaeman, S., Malawat, M., \& Darma, D. (2019). Konstruksi Makna

Bakupukul Manyapu bagi Masyarakat Mamala Maluku. Jurnal Antropologi: Isu-Isu Sosial Budaya, 21(1), 61-72.

Syam, S. (2018). Tradisionalisme Islam Suatu Karakter Dan Pola

Pengembangan Islam Di Indonesia. Al-Hikmah: Jurnal Dakwah dan Ilmu Komunikasi, 20-30.

Syarbini, H. A. (2011). Islam dan Kearifan Lokal (Local Wisdom): Menelusuri Nilai-nilai Islam dalam Praktik Ritual Adat Masyarakat Banten. In The 11 Th Annual Conference on Islamic Studies (p. 170). Tara, T. (2017). Memahami Model-Model Teologi Kontekstual Stephen B. Bevans dalam Konteks Budaya Ende-Lio sebagai Bagian dari Kejujuran Berteologi. Atma Reksa: Jurnal Pastoral dan Kateketik, 2(1), 4859.

Triwahyuni, E., Hasanah, U., \& Nur, S. M. (2020). Tradisi Sedekah Tolak Bala pada Masyarakat Desa Langkan Kecamatan Banyuasin III Kabupaten Banyuasin.

Wijarnako, B. (2013). Pewarisan Nilai-Nilai Kearifan Tradisional dalam Masyarakat Adat (Peranan Kepala Adat dalam Mewariskan aturan Adat di Kampung Adat Dukuh Desa Cijambe, Kecamatan Cikelet, Kabupaten Garut, Propinsi Jawa Barat). Jurnal Geografi Gea, 13(2).

Zuhri, H. (2018). Living Islam Apa dan Mau ke Mana?. Living Islam: Journal of Islamic Discourses, 1(1), 1-30. 